\title{
Examining the "Reluctant Task" from the Perspective of Verses and Hadith
}

\author{
Ameneh Omidi; Mohammad Salmani; Seyed Majid Nabavi \\ PhD Student in Quran and Hadith Shahid Chamran University of Ahvaz, Ahvaz, Iran. Email: omidi7092@yahoo.com \\ PhD Student in Political Science, Islamic Azad University, Karaj Branch, Iran. Email: Fasls180@gmail.com
}

PhD Student in Quran and Hadith Arak University, Iran. Email: majidnabavi1366@gmail.com

https://doi.org/10.47814/ijssrr.v3i4.56

\begin{abstract}
Reluctance means forcing a person to do or leave something he hates. This research seeks to answer the question that what do the verses and narrations have about the task? In other words, what are the Quranic documents and the narration of the task? The method of collecting materials in this research is library and the research method is descriptive and analytical. In many verses, especially verse 106 of Surah An-Nahl, the Qur'an refers to the discussion of relieving one's duty reluctantly, due to the revelation of this verse. When the infidels forced some people like Ammar to say blasphemous words, he also uttered those words in order to save his life. Say the same words. It is understood from this verse that in cases of reluctance, there will be no obligation on individuals. Some narrations also discuss "relieving a duty with reluctance", including "the hadith of relieving"(The Messenger of God (s) said: Raise her from her nation to expand her line and mankind, and do not thank her for her and Recitation: The Prophet said: 9 things have been taken away from my ummah and they will not be punished for it: 1-Error; 2- Forgetfulness, 3-Work that is done reluctantly, etc.) which in this narration the Prophet (PBUH) has abolished the penal effects in case of special circumstances. In addition to verses and hadiths, jurisprudence and reason also rule out the obligation if there is reluctance. Therefore, verses and hadiths have considered the obligation in conditions of reluctance to be abrogated and the person in case of doing something reluctantly; Will not be punished.
\end{abstract}

Keyword: Hadith of Removal; Reluctance; Urgency; Compulsion; Removal of Duty

\section{1-Expressing the Problem}

Discussing the issue of relieving a task by reluctance and forcing others to do something is an issue that has religious roots and religion and reason confirm the removal of a task in case of reluctance; It is necessary to study reluctance from different aspects, especially the Qur'an and Hadith to clarify its dimensions. This post seeks to answer what reluctantly solves the task and that What do the Qur'an and hadiths say about reluctance? 


\section{2-Examining the Meaning of Reluctance and Solving the Task and Its Conditions}

To better understand the issue, it is necessary to explain the word "reluctance" and the concept of homework and then discuss it.

\section{2-1-Literary Meaning}

The famous lexicographer Farahidi did not provide a definition for reluctance and only gave a few examples (Farahidi, 1410, vol. 3, p. 376), but other lexicologists have provided a meaning for it, which is mentioned below:

Reluctance means to force, and "butter" with conquest means suffering and hardship (Fayumi, 1383, vol. 2, p. 531). (Mustafavi, 1989, vol. 10, p. 49). What is ugly is called ugly (Firoozabadi, 1383, vol. 2, p. 1644). Ibn manzoor means butter (with adjective) meaning what the soul hates; He knows (Ibn Manzur, 1373, vol. 13, p. 534) and Korea (with conquest) also means what the other forces you to do; Has known. (Ibn Manzoor, 1373, vol. 12, p. 80) Zubaydi says in Taj al-Arus: Butter (with conquest) is a hardship that reaches man from outside and is imposed on him reluctantly, and butter (with attachment) is a hatred that comes from within It hurts people. (Zubaydi, Bita, vol. 36, p. 485)

\section{2-2-Terminological Definition}

Reluctance is forcing a person to do something that he would not have done if he was not afraid of material, spiritual or physical harm caused by the reluctant threat (Najafi, 1983, vol. 32, p. 11). Reluctantly, the obligatory obligation of removing and punishing the obligatory abandonment or committing haram is removed from Makra (Ansari, Bita, vol. 4, p. 442). Disgust is forcing a person to do or leave something that he is dissatisfied with (Najafi, 1983, vol. 32, p. 11). Jorjani in the definition of reluctance says: Reluctance is the obligation and compulsion of man to something that his nature or sharia dislikes and in spite of dissatisfaction, he acts to eliminate more severe harm. (Jorjani, 1991, pp. 27 and 50) Reluctance means forcing someone else to do something, along with threats and intimidation.

It should be noted that this action is sometimes done rightly; Such as forcing a monopolist to sell hoarded goods and sometimes unjustly; Such as a person's reluctance to perform a haram act or to leave an obligatory act, or the creation of a special contract or agreement by a tyrant. (Meshkini Ardabili, 2005, p. 84)

\section{2-3-Homework}

Duty means to address the Shari'ah to do or leave work or to choose between the two, and the term includes obligation, sanctity, recommendation, hatred and obscenity. (Hashemi Shahroudi, 1426 AH; vol. 2; p. 609) And the removal of the duty means that the cases that the shari'ah has required the person to do will be removed and there will be no punishment for it. In other words, the punishments (whether worldly or otherworldly) that exist for some actions if that action is in certain circumstances, such as reluctance; Will be canceled.

\section{2-4-Terms of Assignment}

Coercion is forcing a person to do something that he would not have done if he had not feared material, spiritual or physical harm from the reluctant threat. 
Researchers have attributed the realization of reluctance to four things:

1- The reluctant threat to the property, life or reputation of the reluctant person or his relatives.

2- Reluctant belief in the reluctant ability to carry out one's threat.

3- Affection of fear on Makra from Makra.

4- Not removing the intention of the verb from the plot. (Hashemi Shahroudi, 1426 AH; vol. 1; p. 630)

\section{3- Reluctance in Quran and Hadith}

The issue of reluctance is mentioned in many verses and hadiths, which are discussed in the following in the Qur'an and Hadith.

\section{3-1-Reluctance in the Quran}

The Qur'an mentions reluctance with various words and interpretations; Including the word "sphere" and its derivatives, which has been used more than 40 times in the Qur'an and in most cases means abrogation; Such as "Ask her if she dislikes something and she is good for you" (Al-Baqarah / 216) And also (Nisa '/ 19) and in some verses it has the idiomatic meaning; Such as "Except for him whose heart and soul are secure" (Nahl / 106) And also (Noor / 33) expressions such as: "la tauzeloohonna" (Nisa / 19) which in a way, refers to reluctance. In these verses, while expressing some jurisprudential rules of reluctance, the worldly and otherworldly effects and consequences of this practice are discussed.

Given that verse 106 of Nahl is more related to the discussion of reluctance, it is necessary to examine the meaning of the verse.

The Holy Quran says in verse 106 of Surah An-Nahl: "My God, my disbelief after E. except me and plowed been shy but I know my upper and Balkfr as Sadra Flyhm lahum my wrath and punishment of God is great."

And whoever denies God after believing, not that he is compelled and his heart is in faith, but that he opens his heart to disbelief, the wrath of God is upon them, and they will have a great retribution.

In the commentary of Majma 'al-Bayan about them, the revelation of this verse is stated: verse "Not that he is forced and his heart is in faith" It has been revealed about Ammar and his father Yasir and his mother Somayeh, Sahib, Bilal and Khabab. They were tortured by infidels. Ammar's parents were killed and Ammar said whatever they wanted and was saved. After that, God informed the Prophet about the incident, some of them said: Ammar has become a disbeliever.

He said: Never, Ammar is full of faith from head to toe and faith is mixed with his blood and flesh. Amar was honored by the presence of the Prophet with tears in his eyes. The Prophet said: What is behind you? He said: O Messenger of God, evil and ugliness. I remembered their gods well and conveyed myself to you. The Prophet, while wiping his eyes, said: If you are still caught in their clutches, repeat the previous words. This is a quote from Ibn Abbas and Qatadah. This practice is called in the term taqiyyah which follows the rules in Islam (Tabarsi, 1372, vol. 14, p. 57). 
The commentators in the interpretation of this verse believe that if a person believes in God and if they are forced to say or do non-Islamic deeds; There is no guilt or punishment on them (Zuhili, 1418, vol. 14, p. 243; Makarem, 1382, volume 11, page 419; Tabarsi, 1372, vol. 14, p. 388; Tabatabai, 1374, volume 12, p. 508; Zamakhshari, 1391, vol. 2, p. 636) and they can do such an action to save lives.

\section{3-2-Reluctance in Hadith}

In various narrations and hadiths, the issue of relieving the task has been mentioned reluctantly for example, Bukhari has categorized the hadiths related to reluctance in his Sahih book (Bukhari, $1315 \mathrm{AH}$, vol. 8, p. 55).

Among the most important hadiths in this field; It is a "hadith of removal" which is examined in the continuation of this hadith from the perspective of Shiites and Sunnis.

\section{3-2-1-Hadith of Removal from the Shiite Point of View}

The most famous narration that has been cited as an argument for the rule of reluctance is the hadith of elimination (Encyclopedia of the Islamic World, 1983, vol. 9, p. 588).

This hadith has been narrated by Shaykh Saduq (Ibn Babawiyyah) that according to this hadith, nine things have been removed from a Muslim: What they do out of urgency, 6 . What they are forced to do (reluctance), 7. Divination, 8. Thinking about creation out of temptation, 9. Envy until it is spoken or spoken.The Messenger of God (s) said: Raise yourself from your nation by expanding the line and the human beings, and do not thank them for it and do not know it.They can not tolerate or are forced into, and envy and volatility, and contemplation of an obscenity in the creation that is not uttered. (Ibn Babuyah, 1362, Part 2, p.417)

The fundamentalists, including Sheikh Ansari, have considered the purpose of elimination to be the removal of its apparent effects. (Al-Behsudi, $1412 \mathrm{AH}$, vol. 2, p. 257) It means that the effects of the eagle and punishment will be removed from these people and these people will not be punished.

\section{3-2-2-Hadith of Removal from the Point of View of Sunnis}

The hadith of elimination in Sunni hadiths is more limited than the Shiite hadith and includes only three things: error, forgetfulness and reluctance. The phrase of the hadith is as follows: "He was removed from what was wrong and forgotten, and what they hated."

(Suyuti, 1373 AH, vol. 2, p. 24) This hadith has been narrated by Ibn Majah, Ibn Habban, Darqatani, Tabarani and Hakim. Sharaf al-Din al-Nawawi, one of the commentators on the hadith and one of the jurists of the Shafi'i religion, called it a hadith of Hassan. (Mohaghegh Damad, 1383, vol. 4, p. 100)

In all cases in which in Sunni jurisprudence reluctance is considered effective in legal or criminal seizure, this hadith has been cited as one of its principles and justifications.

\section{4-Reluctance in Islamic Jurisprudence}

Since obligatory actions are the subject of the science of jurisprudence, this characteristic of having performed the obligatory action in conditions of reluctance is of great importance both in terms of obligatory rulings and in all situations. Because reluctance may be applied to acts of worship, transaction, or any other 
act, in fact, no chapter of the jurisprudential chapters is separate from the subject of reluctance.Hence, in the jurisprudential texts of various religions, one can find cases of reluctance to discuss the subject of reluctance in each chapter. The issue of reluctance has often been addressed on a case-by-case basis, and has seldom been considered as an independent issue. Limited examples of the independent design of this subject can be seen in the works of the Hanafi religion, and the first example is the book of Al-Ikrah by Muhammad ibn Hasan al-Shaybani, mentioned by Ibn Nadim (Ibn Nadim, 1343, vol. 1, p. 257).After Sheibani, the Hanafi jurists continued this work, so that in works such as Muksut Sarakhsiya (Sarakhsiya Mohammad, Bita, vol. 24, p. 38), and Hedayeh Marghinani, (Ali Marghinani, 1315 AH, vol. 7, p. 292) It is considered as one of the books of jurisprudence.

Regarding reluctance in cases of limits in jurisprudence, it should be said that punishment is possible only if it is voluntary, and the person who does something reluctantly does not lose responsibility. Some cases where the sentence is revoked due to reluctance as follows:

1- Reluctance to commit adultery (Har Ameli, 1403 AH, vol. 28, p. 110) Imam Baqir (AS) also said: "There is no limit to a woman who is reluctant to commit adultery, neither cover nor stoning nor exile" (Tabarsi, 1372, vol. 14, Page 50) The Sunnis also believe that if a woman is forced to commit adultery, she is different from the woman who did it voluntarily. (Odeh, Abdul Qadir, Bita, p. 367)

2- Reluctance to drink alcohol (Hassan Ibn Hali, 1374, p. 156). If the drinker is sentenced to the extent that he is free (Khoei, 1386, vol. 1, p. 276; Zahili, 1371, p. 150)

3- Reluctance to steal (Najafia, Mohammad Hassan, vol. 21, p. 30).

4- Reluctance to fast (Har Ameli, 1403 AH, vol. 2, p. 90).

5- A person who has gone to Hajj and reluctantly performs an action that invalidates Hajj. (Ibid., Vol. 2, p. 354).

6- Reluctance on vows and oaths (Ibid., Vol. 3, p. 35

7- Reluctance to break vows and oaths (Ibid., Vol. 3, p. 56).

\section{5-Examining the Rule of Reluctance from the Perspective of Reason}

Rationally, discretion and freedom of will are the foundations of criminal responsibility. If one does not have authority or any restrictions are placed on it, criminal responsibility is no longer imposed on the person; And reason cannot be ruled on responsibility and its realization.

Therefore, regardless of the Shari'a rules and movable documents that have been cited in Islamic texts as a justification for the removal of responsibility from the deceitful person, relying on rational reasoning can also be done in cases where the person is reluctant and in order to get rid of the danger from the area. The reluctant one threatens himTo take action that is considered a violation of Sharia or legal regulations in normal circumstances, ordered the non-fulfillment of responsibility and the prohibition of punishment and punishment. This reaffirms the fact that reluctance has found its way into customary law, which is independent of sharia rules and inspired by human reason. 


\section{6-The Difference Between Reluctance and Urgency and Its Difference with Compulsion}

Reluctance is common to concepts such as urgency and coercion because in all three, a person is forced to do or quit something, but there are differences. Reluctance and urgency differ in that there is no esoteric satisfaction in reluctance. Rather, the action is done with threats and intimidation, but in an emergency, special social, economic, or natural disasters force the person to do something that he is satisfied with inwardly, so dealing with the deceitful is void and dealing with the distressed is correct. ، ص ، 1384 74) Because the criterion for the validity of the transaction is the compromise of the parties "If only it is a trade against mutual consent" (Women / 29) Where is the criterion of Dard obliged to exist.

The difference between the two and coercion is that in reluctance and urgency, contrary to coercion, will and authority are not taken away from man; For example, if the head of a fasting person is submerged in water and overcome, he is completely deprived of his authority. His fast will not be invalidated.Because the fulfillment of the moment (the invalidation of a day) was not in his will; But if he commits such an act out of reluctance or urgency, because his will has not been taken away from him, his fast is void (Yazdi, Bi Ta, vol. 2, p. 21).

\section{Result}

Based on the issues raised, it was concluded that the verses and narrations on the removal of duty (and the abolition of punishment) Reluctantly point out One of the most important verses that refer to the discussion of relieving the task reluctantly is verse (Al-Nahl / 106). He who disbelieves in God after his faith, but he who hates him and whose heart is reassured by faith. Translation: Whoever disbelieves in God after believing in himself [will have a severe punishment] except the one who is compelled, and [his] heart is confident in faith. But whoever opens his chest to disbelief, the wrath of God is upon them, and for them is a great punishment.

And one of the most important narrations that refers to relieving the task reluctantly is the hadith of relieving in which the Prophet (s) said: Effective for my nine error and forgetfulness, and what forced him and what do not know and what can not afford and what they had to and envy and Tira and reflect on the creation Meticulousness unless pronounced lip.Translation: Nine things have been taken away from my ummah (that is, they will not be reprimanded for these 9 things) error and forgetfulness, and what they do reluctantly and compulsively, and what they do not know, and what they do not have the strength (malaitiqun), and what They do urgency and envy until it is spoken or caused by action, and fortune-telling and temptation to think of creation.

This hadith is brief in Sunnis and includes only the first 3 cases.

Reluctance is also discussed in jurisprudence and jurisprudence has stated some cases of it (such as reluctance to commit adultery and reluctance to steal, etc.) which, if acted upon reluctantly; There will be no punishment for the person. In addition to religious texts, reason does not consider reluctant action to be punishable because intellectually, the person who performs the action must have the freedom and authority to be punished.

Therefore, the Qur'an, narrations, jurisprudence and reason all dictate the reversal of punishment in practice by reluctance, and the reluctant person should not be like a free and reluctant person; Be punished. 


\section{References}

Al-Behsudi, Al-Waiz Al-Husseini, Mesbah Al-Osul, Maktab Al-Dawari Publications, Qom, 1412.

Ansari, Faraid al-Osul, numbers for the investigation of the legacy of Sheikh al-Azam, Qom, Islamic Thought Association, 1390.

Ansari, Mohammad Ali (Shushtari Caliph); The encyclopedic jurisprudence of Egypt, Bita, Qom, Shariat Publications.

Bukhari, Mohammad, Sahih, Istanbul, 1315 AH.

Fayrouz Abadi, Muhammad ibn Yaqoub, The Surrounding Dictionary, Dar al-Kitab al-Ilmiyya, Muhammad Ali Baydoun Publications, Beirut, 1383.

Hashemi Shahroudi, Mahmoud, Farhan, Jurisprudence corresponding to the doctrine of the people of the House, peace be upon them, 5 vassal, founded by the Department of Knowledge Islamic jurisprudence in the right of the doctrine of the people of the House, peace be upon them, the Center of Gohshahi Farsi Al-Ghadeer - Iran - Qom, Jav: 1, 1426 AH.

Hor amoli, mohammad; vasael Shiite, corrected by Sheikh Mohammad Razi, Tehran, Islamic Library, 1403 $\mathrm{AH}$.

Ibn Babawiyyah, Muhammad ibn Ali, Al-Khasal, translated by Yaqub Ja'fari, Teachers Association, Qom, 1983.

Ibn Manzoor, Muhammad Ibn Makram, Arabic Language, Institute of Arabic History, Beirut, 1373.

Jorjani, Ali Ibn Mohammad, Definitions 1991, Nasser Khosrow, Tehran.

Khoei, Seyed Abolghasem; Fundamentals of completing the curriculum, Al-Adab Press, Najaf Ashraf, 2007.

Makarim Shirazi, Nasir, Tafsir Namouneh, Dar Al Kotob Al Islamiyyah, Tehran, 1374 AM.

Marginani, Ali, Al-Hediyyah, Hamrah Ba Sharh Fath al-Qadr, Cairo , 1919 B.C.Marginani, Ali, AlHediyyah, Hamrah Ba Sharh Fath al-Qadr, Cairo , 1919 B.C.

Mashkini Ardabili, Ali, Terms of Fiqh and most of its subject titles, 1384, Hady publication, Qom.

Mohaqiq Damad, Mustafa, Fiqh Rules, Islamic Sciences Publishing Center, Tehran, 1383.

Mustafa Hassan; Investigating the words of the Noble Qur'an, and visited Farahn and Islamic guidance, 1368 AM.

Najafi, Mohamed Hassan; Jawaher Al-Kalam, 1362, Beirut, Arab Heritage Revival House, Beirut.

Odeh, Abdel-Qader, Criminal Law, Beirut, Dar Al-Kitaab Al-Arabi, Beta.

Sarkhasev, Muhammad, Al-Mabsut, Cairo, Al-Istiqah Press, Pty.

Sayotee, Jalal ad-Din, Al-Saghir Mosque, Cairo 9, 18 BC.

Tabarsi, Majma 'al-Bayan fi Tafsir al-Qur'an, Tehran, Islamic Scientific Library, 1372.

Tabatbay, Sayyid Muhammad Husayn, Al-Mizan, Book of Islamic Spreads, University of Teachers of the College of Science Qom, Qom, 1374 st.

Yazdi, Sidakazem, PTA, Al-Alamy Foundation for Publications, Beirut.

Zahili, Islamic jurisprudence and its evidence, Medin, Qom, 1371.

Zahili, Wehbe bin Mustafa, The Enlightening Interpretation of Belief, Sharia and Methodology, Dar Al-Fikr Contemporary, Beirut - Damascus, 1418.

Zamakhshari, Mahmoud, Revealing the Truths of the Mysteries of the Download, Dar Al-Kitaab Al-Arabi, Beirut, 1407 BC.

Zebidi, Muhammad bin Muhammad, Crown of the Bride from the Jewels of Al-Qamous, Dar Al-Fikr, Beirut, Bey. 


\section{Copyrights}

Copyright for this article is retained by the author(s), with first publication rights granted to the journal.

This is an open-access article distributed under the terms and conditions of the Creative Commons Attribution license (http://creativecommons.org/licenses/by/4.0/). 